\title{
Embryo coculture: A review
}

\author{
Alexis P Melnick, Steven D Spandorfer* \\ The Ronald O. Perelman and Claudia Cohen Center for Reproductive Medicine, Weill Cornell Medical College, New York, \\ United States
}

Received: July 30, 2015

Accepted: September 1, $2015 \quad$ Online Published: September 21, 2015

DOI: $10.5430 /$ jer.v2n1p15

URL: http://dx.doi.org/10.5430/jer.v2n1p15

\begin{abstract}
Since the inception of in-vitro fertilization, various attempts have been made to improve in-vitro embryo development, thereby enhancing implantation and in turn, pregnancy rates. Coculture, the simultaneous culture of somatic cells together with the embryo, is one strategy that has been used to achieve this goal. We review the rationale behind the technique of coculture, current methods utilized, and the evidence supporting its use.
\end{abstract}

Key Words: In-vitro fertilization, Coculture, Implantation, Endometrial cells

\section{INTRODUCTION}

The success of an in-vitro fertilization-embryo (IVF-ET) cycle is dependent on the ability of an embryo to implant. In-vitro culture conditions, therefore, are crucial to IVF cycle outcome. Since the development of IVF, several strategies at improving culture conditions to closely mimic the in vivo environment have been made. The use of an embryo coculture systems using "helper" cells is one such approach that may afford benefit to certain patients, specifically those with history of poor embryo quality or repeated implantation failure.

The initial studies of embryo coculture took place in animals. In 1965, Cole and Paul demonstrated improved blastulation rates with culture of mouse embryos on a HeLa cell line. ${ }^{[1]}$ The use of such helper cell lines then gained popularity during the 1970s in the field of domestic animal biotechnology. Embryo transfer in animals must be performed at the blastocyst stage; transfer at earlier stages leads to expulsion of embryos from the vagina. However, this posed a challenge, as in-vitro culture conditions were unable to sustain continued embryonic development. Embryos arrested at the maternal to zygotic transition (MZT), the stage in embryonic development during which development comes under the exclusive control of the zygotic genome. This transition, which occurs at different cell stages in different mammalian species, occurs during early embryo development in an extended cell cycle characterized by zygotic genome activation and degradation of maternal mRNAs. ${ }^{[2]}$ After this shift, the embryo is autonomous. Early animal pre-embryos cultured in-vitro displayed specific developmental blocks related to this transition and blastulation rates were low. ${ }^{[3]}$ As such, strategies to improve embryo culture and overcome such blocks were sought. Coculture, defined as the simultaneous culture of somatic cells together with the embryo, emerged as an attractive strategy to mimic in vivo culture conditions. Coculture of bovine embryos with trophoblastic vesicles began in the early 1980s and was the first protocol to allow for blastocyst culture and ultimately, live birth. ${ }^{[4]}$ Subsequent mammalian coculture systems successfully employed both oviduct epithelial cells and uterine cells. ${ }^{[5]}$

Given the favorable results obtained in animals, the adaptation of coculture systems to human IVF was a logical next step. In 1989, Wiemer, et al. demonstrated improvements in morphology, implantation rate, and clinical pregnancy rate

\footnotetext{
* Correspondence: Steven D Spandorfer, MD; Email: sdspando@med.cornell.edu; Address: The Ronald O. Perelman and Claudia Cohen Center for Reproductive Medicine, Weill Cornell Medical College, 1305 York Avenue, 6th Floor New York, NY, United States.
}

Published by Sciedu Press 
for embryos cultured on bovine uterine epithelial cells compared with conventional media. ${ }^{[6,7]}$ Bongso, et al., in the same year, demonstrated improvements in embryo quality among embryos cultured with human oviduct epithelial cells obtained from women undergoing hysterectomy. ${ }^{[8]}$ These initial studies led to optimism that the coculture of human embryos would lead to an optimized in-vitro environment and in turn, improvements in IVF cycle outcomes. Multiple cell types have been used in coculture systems ranging from human oviducts, endometrium, and cumulus-granulosa cells to nonhuman cells lines such as Vero cells and bovine uterine epithelial cells, to ovarian carcinoma cell lines. Today, due to concerns regarding disease transmission from nonhuman or homologous feeder cell lines as well as a 2002 FDA warning classifying the use of nonhuman feeder cell lines as xenotransplantation, the use of coculture is limited to the use of autologous endometrial cells.

\section{TECHNIQUES}

Regardless of the cell type used, a coculture system requires three crucial components: culture medium, somatic cells, and embryo. Somatic cells as feeders can be used as cell suspensions, pieces of tissue, or in monolayers. While there is no general consensus as to the best type of coculture system, there are clearly some cell types that function better than others. Somatic cells chosen for use in a coculture system must promote embryonic development and must be compatible with the human embryo. Fibroblasts, for example, are poor feeder layers for embryo culture for two reasons. First, fibroblasts continue to divide in culture leading both to depletion and acidification of culture medium. Second, growth factors secreted by fibroblasts do not have any counterpart receptors on the embryo. Epithelial cells appear to be most suited to promoting embryonic development - however, the best type of epithelial cell to use is still debated. ${ }^{[9]}$ Vero cells, an established cell line derived from Green Monkey Kidney, have been utilized extensively for the study of human embryo coculture. These cells are highly controlled and easy to handle and manipulate and as such can be easily incorporated into an IVF unit. However, concerns about disease transmission from nonhuman cells limit their use. Today, autologous endometrial coculture (AECC) systems have replaced the use of nonhuman or homologous cell types. Endometrial cells offer several advantages for use in a coculture system; they are easily available, can be obtained via biopsy in a prior cycle, and in vivo, are involved in peri-implantation embryonic development. Though specific protocols for AECC vary from center to center, the basic principles are the same. Briefly, luteal phase endometrial sampling is performed prior to an IVF cycle. Endometrial tissue then undergoes enzy- matic digestion and separation and is cryopreserved. Cells are subsequently thawed during the patient's IVF cycle and are added to media supplemented with the patient's serum. While the use of autologous endometrial cells precludes any chance for disease transmission, there are several problems encountered with the use of non-established cell lines as feeder layers. These include difficulty in obtaining subpassages after trypsinization, rapid aging, and rapid attrition of trophic capacities. ${ }^{[9]}$

\section{MeChanisms OF ACTION}

Coculture is proposed to influence embryo development via several mechanisms. These include the release of embryotrophic factors and the detoxification of the culture medium by removal of heavy metal cations, free radicals, or metabolic inhibitors. ${ }^{[10-13]}$ The goal of the coculture system is to provide factors that will allow the embryo pass the critical stage of MZT, allowing for full development. Such cytokines and growth factors must be active during the first three days of culture to increase the metabolic activity of the human embryo, thereby increasing its potential to develop and implant. ${ }^{[14]}$ Embryonic feeder cells in both animal and human culture systems have been shown to secrete various cytokines and growth factors. In 1997, Barmat et al. utilized Northern Blot analysis to demonstrate expression of transcripts encoding epidermal growth factor (EGF), Kitligand, colony-stimulating factor-1 (CSF-1), leukemia inhibitory factor (LIF), and interleukin-6 (IL-6) in RNA derived from human oviduct cell lines and buffalo rat liver cells. ${ }^{[10]}$ Paria and Dey demonstrated a paracrine/autocrine relationship between transforming growth factor $\beta-1$ (TGF $\beta$ 1) during murine embryo development. ${ }^{[15]}$ These secreted factors have been shown to positively correlate with embryo development, quality, and subsequent pregnancy outcomes. Coculture cell lines have also been implicated in removal of deleterious media components such as hypoxanthine and oxygen metabolites, both of which are known to hamper embryo development. ${ }^{[16,17]}$ Interestingly, the embryotrophic effect of coculture feeder layers is hormone-independent. This hypothesis was first generated by bovine studies utilizing trophoblastic vesicles derived from D18 embryos. ${ }^{[4]}$ Studies utilizing prepubertal oviduct cells as feeder layers and de-synchronized tubal or uterine cells in coculture then confirmed this theory. ${ }^{[18]}$

Given the crucial role of the endometrium during the window of implantation, the use of endometrial cells in coculture as a method to enhance implantation makes sense. Data from several studies demonstrate evidence of a cross-talk between the developing embryo and the maternal endometrium. ${ }^{[19]}$ This dialogue may not only promote embryo development, 
but may also activate specific paracrine factors that increase the likelihood of implantation. ${ }^{[20]}$ In 1996, De los Santos demonstrated that a coculture system with human endometrial epithelial cells leads to increased secretion of embryonic paracrine markers. ${ }^{[21]}$ Furthermore, the same group demonstrated that embryos cultured in endometrial epithelial cells improved uterine receptivity by upregulating certain key adhesion molecules. ${ }^{[22]}$ In 2001, Spandorfer, et al. demonstrated the presence of LIF in coculture media and showed a positive correlation between LIF levels and embryonic development and clinical pregnancy rates. ${ }^{[23]}$ As with animal studies, these effects of endometrial cells are independent of hormones; coculture with human endometrial cells represents a de-synchronization as uterine biopsies are obtained during the luteal phase.

\section{Outcomes}

The goal of embryo coculture is to enhance embryonic development during the crucial period of MZT, thereby increasing implantation potential. This is especially important for "borderline" embryos that would have otherwise arrested in-vitro. There have been several studies in the literature evaluating the use of coculture in human IVF with contradictory results. Early studies demonstrated improvements in pre-embryo grade, an increase in average number of blastomeres, and a decrease in fragmentation rates with coculture of embryos on nonhuman cell lines. ${ }^{[6-8]}$ Morgan et al. for example, demonstrated decreased fragmentation, increased blastomere expansion, and improved clinical pregnancy rates for embryos cocultured with bovine oviduct epithelial cells compared with controls. ${ }^{[24]}$ Similarly, Magli, et al., randomized patients to conventional media or coculture on a Vero cell layer and found a higher cleavage rate and improved embryo morphology in the coculture. ${ }^{[25]}$ However, the group failed to find difference in blastulation rates or pregnancy outcomes. Tucker et al. reported improved post-thaw blastomere survival of cryopreserved embryos cocultured with bovine oviductal epithelial cells. ${ }^{[26]}$ Wiemer, et al. also demonstrated a benefit to coculture on the same bovine cell type in patients with a history of multiple failed IVF cycles in terms of embryo quality, implantation rates, and pregnancy outcomes. ${ }^{[27]}$ Other studies, conversely, have not shown any advantage to use of a nonhuman coculture system on human embryo development, implantation, and pregnancy rates. ${ }^{[28-30]}$ Tucker, et al., for example, found no differences in the pregnancy rates using the same cell line as the aforementioned study by Wiemer, et al.

Coculture of embryos using human cells, both homologous and autologous, has produced similarly conflicting results. Jayot, et al., in an early study using homologous endome-

Published by Sciedu Press trial cells, showed improved pregnancy rates after coculture in patients with repeated implantation failure. ${ }^{[31]}$ Nieto $e t$ al., in a randomized trial comparing autologous endometrial coculture to conventional media, showed improvements in fragmentation but failed to demonstrate a difference in early cleavage rate. ${ }^{[32]}$ Since 2002, when the FDA recommended against the use of non-human coculture cell lines in human IVF, the use of coculture has been limited to the use of autologous endometrial cells. The literature reflects this change. The majority of studies published on autologous endometrial coculture systems have been published by our center at Weill Cornell Medical College and by IVI in Valencia, Spain. The Cornell group has published several studies demonstrating improvements in blastomere number and decreases in fragmentation rate in patients with a history of poor embryo quality and failed implantation. ${ }^{[33-35]}$ All patients in these studies underwent embryo transfer on day 3 . The IVI group has investigated the use of AECC with extended culture to the blastocyst stage. Simon, et al. in 1999, in a study of women with repeated implantation failure, showed improvements in implantation and pregnancy rates among women undergoing oocyte donation with blastocyst transfer. ${ }^{[36]}$ However, this study failed to find a difference in women undergoing IVF with autologous oocytes. A follow-up study in 2003 demonstrated no adverse perinatal outcomes in women who had undergone blastocyst transfer after AECC. ${ }^{[37]}$ A more recent study by the same group of over 12,000 embryos comparing AECC to a sequential media system, found a highly significant difference in blastocyst formation rates in the AECC cohort. ${ }^{[38]}$ A 2010 study of 68 couples with history of IVF failure demonstrated significant improvements in implantation and pregnancy rates for both fresh and frozen embryo transfers with utilization of an AECC system. Implantation rates increased from $1.6 \%$ to $24.5 \%$ for fresh transfers and from $2.9 \%$ to $17 \%$ for frozen transfers and pregnancy rates from $4.3 \%$ to $53 \%$ for fresh and $7.4 \%$ to $38 \%$ for frozen. ${ }^{[39]}$ Despite these favorable results, the technique remains controversial and its use, limited. This is evident from the paucity of coculture studies published in the past ten years.

An accurate analysis of coculture and its effects is difficult using the existing literature due to the heterogeneity of coculture techniques used and lack of well-controlled, welldesigned studies. There is tremendous variation both in type of cell line utilized for coculture and the exact methods employed. Furthermore, most studies are retrospective without adequate control groups or power. Lastly, assessment of embryo development and morphology is highly subjective and is not standardized. A 2008 meta-analysis by Kattal, et al. which pooled randomized trials of coculture, did show a significant benefit to coculture with improvements in blas- 
tomere number, implantation rate, and clinical and ongoing pregnancy rates. ${ }^{[40]}$ However, the analysis did not include any studies of AECC, the predominant coculture method currently used, as there have been no randomized controlled trials of the method. Large, randomized, multicenter trials are needed to appropriately evaluate this technique.

Several criticisms have been leveled against the use of coculture techniques since their initial use. These include the risk of disease transmission from nonhuman or homologous cell lines, effect on perinatal outcomes, and ease of implementation into the IVF laboratory. Concerns regarding disease transmission led to the abandonment of non-autologous coculture in IVF. As discussed earlier, the use of autologous cells poses several challenges and may not provide the same benefit to embryo growth and development as established cell lines. Desai, et al. have investigated the use of an established human endometrial cell line in coculture. Their results thus far have been promising with the line demonstrating embryotrophic properties and comparing favorably to both Vero cells and human oviductal cells as a co-culture system. ${ }^{[41,42]}$ In 2003, the group reported a novel non-contact human endometrial co-culture system using this endometrial cell line

\section{REFERENCES}

[1] Cole R, Paul J. Properties of cultured preimplantation mouse and rabbit and cell strains developed from them. In: Colak D, Wolstenholme GEW, editors. Preimplantation stages of pregnancy. Boston,: Little, Brown; 1965. p. 82-155.

[2] Baroux C, Autran D, Gillmor CS, et al. The maternal to zygotic transition in animals and plants. Cold Spring Harbor symposia on quantitative biology. 2008; 73: 89-100. Epub 2009/02/11. PMid: 19204068. http://dx.doi.org/10.1101/sqb. 2008.73.053

[3] Telford NA, Watson AJ, Schultz GA. Transition from maternal to embryonic control in early mammalian development: a comparison of several species. Molecular reproduction and development. 1990; 26(1): 90-100. Epub 1990/05/01. PMid: 2189447. http://dx.doi.org/10.1002/mrd.1080260113

[4] Camous S, Heyman Y, Meziou W, et al. Cleavage beyond the block stage and survival after transfer of early bovine embryos cultured with trophoblastic vesicles. Journal of reproduction and fertility. 1984; 72(2): 479-85. Epub 1984/11/01. PMid: 6512770.

[5] Gandolfi F, Moor RM. Stimulation of early embryonic development in the sheep by co-culture with oviduct epithelial cells. Journal of reproduction and fertility. 1987; 81(1): 23-8. Epub 1987/09/01. PMid: 3668954. http://dx.doi.org/10.1530/jrf.0.0810023

[6] Wiemer KE, Cohen J, Wiker SR, et al. Coculture of human zygotes on fetal bovine uterine fibroblasts: embryonic morphology and implantation. Fertility and sterility. 1989; 52(3): 503-8. Epub 1989/09/01 PMid: 2776903.

[7] Wiemer KE, Cohen J, Amborski GF, et al. In-vitro development and implantation of human embryos following culture on fetal bovine uterine fibroblast cells. Hum Reprod. 1989; 4(5): 595-600. Epub 1989/07/01. PMid: 2794019. and Transwell plates. ${ }^{[43]}$ This strategy allows for embryos in culture to benefit from secreted embryotrophic factors while preventing contact with endometrial cells, thereby lowering the theoretical risk of disease transmission. Concerns regarding perinatal safety of coculture procedures appear to be unfounded; transfer of both cleavage-stage embryos and blastocysts after coculture has led to perinatal outcomes comparable to IVF without coculture.

\section{Conclusion}

The optimization of in-vitro culture conditions is crucial for the success of an IVF cycle, particularly for patients with repeated implantation failure. Several attempts to mimic the in vivo environment through use of a coculture system have, thus far, yielded favorable results. Coculture systems may work via promotion of embryo development through maternal zygotic transformation and secretion of pro-implantation cytokines and growth factors. However, the literature to date is highly heterogeneous with varied results. Large, prospective studies are needed to better evaluate the use of coculture and better define its method of application. For now, coculture remains an effective tool in the arsenal of ART techniques for select patient populations.

[8] Bongso A, Soon-Chye N, Sathananthan H, et al. Improved quality of human embryos when co-cultured with human ampullary cells. Hum Reprod. 1989; 4(6): 706-13. Epub 1989/08/01. PMid: 2778057.

[9] Menezo Y, Servy E, Veiga A, et al. Embryo culture methods and protocols. 2012. In: Methods in molecular biology [Internet]. New York: Humana Press; [231-47].

[10] Barmat LI, Worrilow KC, Paynton BV. Growth factor expression by human oviduct and buffalo rat liver coculture cells. Fertility and sterility. 1997; 67(4): 775-9. Epub 1997/04/01. PMid: 9093210. http://dx.doi.org/10.1016/S0015-0282(97)81382-9

[11] Pampfer S, Arceci RJ, Pollard JW. Role of colony stimulating factor-1 (CSF-1) and other lympho-hematopoietic growth factors in mouse pre-implantation development. BioEssays : news and reviews in molecular, cellular and developmental biology. 1991; 13(10): 535-40. Epub 1991/10/01. PMid: 1836724. http://dx.doi.org/10.10 02/bies. 950131007

[12] Loutradis D, John D, Kiessling AA. Hypoxanthine causes a 2cell block in random-bred mouse embryos. Biology of reproduction. 1987; 37(2): 311-6. Epub 1987/09/01. PMid: 3676390. http: //dx.doi.org/10.1095/biolreprod37.2.311

[13] Fukui Y, McGowan LT, James RW, et al. Factors affecting the in-vitro development to blastocysts of bovine oocytes matured and fertilized in-vitro. Journal of reproduction and fertility. 1991; 92(1): 125-31. Epub 1991/05/01. PMid: 1905351.

[14] Menezo Y, Elder K. The enhancers of oocyte competence. In: Tosti E, Boni R, editors. Oocyte maturation and fertilization: a long history for a short event. Sharjah: Bentham Science Publishers Ltd; 2011. p. 64-70.

[15] Paria BC, Dey SK. Preimplantation embryo development in-vitro: cooperative interactions among embryos and role of growth factors. 
Proceedings of the National Academy of Sciences of the United States of America. 1990; 87(12): 4756-60. Epub 1990/06/01. PMid: 2352946. http://dx.doi.org/10.1073/pnas.87.12.4756

[16] Loutradis D, John D, Kiessling AA. Hypoxanthine Causes a 2Cell Block in Random-Bred Mouse Embryos. Biology of reproduction. 1987; 37(2): 311-6. PMid: ISI:A1987K260200010. http: //dx.doi.org/10.1095/biolreprod37.2.311

[17] Fukui Y, Mcgowan LT, James RW, et al. Factors Affecting the Invitro Development to Blastocysts of Bovine Oocytes Matured and Fertilized Invitro. Journal of reproduction and fertility. 1991; 92(1): 125-31. PMid: ISI:A1991FN32300014.

[18] Thibodeaux JK, Menezo Y, Roussel JD, et al. Coculture of in-vitro fertilized bovine embryos with oviductal epithelial cells originating from different stages of the estrous cycle. Journal of dairy science. 1992; 75(6): 1448-55. Epub 1992/06/11. PMid: 1500550. http: //dx.doi.org/10.3168/jds.S0022-0302 (92) 77900-4

[19] Cross JC, Werb Z, Fisher SJ. Implantation and the placenta: key pieces of the development puzzle. Science. 1994; 266(5190): 150818. Epub 1994/12/02. PMid: 7985020. http://dx.doi.org/10. $1126 /$ science. 7985020

[20] Tazuke SI, Giudice LC. Growth factors and cytokines in endometrium, embryonic development, and maternal: embryonic interactions. Seminars in reproductive endocrinology. 1996; 14(3): 231-45. Epub 1996/08/01. PMid: 8885054. http://dx.doi.org $/ 10.1055 / \mathrm{s}-2007-1016333$

[21] De los Santos MJ, Mercader A, Frances A, et al. Role of endometrial factors in regulating secretion of components of the immunoreactive human embryonic interleukin-1 system during embryonic development. Biology of reproduction. 1996; 54(3): 563-74. Epub 1996/03/01. PMid: 8835377.

[22] Simon C, Gimeno MJ, Mercader A, et al. Embryonic regulation of integrins beta 3 , alpha 4 , and alpha 1 in human endometrial epithelial cells in-vitro. The Journal of clinical endocrinology and metabolism. 1997; 82(8): 2607-16. Epub 1997/08/01. PMid: 9253342. http: //dx.doi.org/10.1210/jcem.82.8.4153

[23] Spandorfer SD, Navarro J, Levy D, et al. Autologous endometrial coculture in patients with in-vitro-fertilization (IVF) failure: correlations of outcome with leukemia inhibiting factor (LIF) production. Am J Reprod Immunol. 2001; 46(6): 375-80. Epub 2002/01/05. PMid: 11775005.

[24] Morgan K, Wiemer K, Steuerwald N, et al. Use of videocinematography to assess morphological qualities of conventionally cultured and cocultured embryos. Hum Reprod. 1995; 10(9): 2371-6. Epub 1995/09/01. PMid: 8530668.

[25] Magli MC, Gianaroli L, Ferraretti AP, et al. Human embryo coculture: results of a randomized prospective study. International journal of fertility and menopausal studies. 1995; 40(5): 254-9. Epub 1995/09/01. PMid: 8556030.

[26] Tucker MJ, Morton PC, Wright G, et al. Enhancement of outcome from intracytoplasmic sperm injection: does co-culture or assisted hatching improve implantation rates? Hum Reprod. 1996; 11(11): 2434-7. Epub 1996/11/01. PMid: 8981127.

[27] Wiemer KE, Garrisi J, Steuerwald N, et al. Beneficial aspects of co-culture with assisted hatching when applied to multiple-failure in-vitro fertilization patients. Hum Reprod. 1996; 11(11): 2429-33. Epub 1996/11/01. PMid: 8981126.

[28] Van Blerkom J. Development of human embryos to the hatched blastocyst stage in the presence or absence of a monolayer of Vero cells. Hum Reprod. 1993; 8(9): 1525-39. Epub 1993/09/01. PMid: 8253948.

[29] Hu Y, Maxson W, Hoffman D, et al. Co-culture with assisted hatching of human embryos using Buffalo rat liver cells. Hum Reprod. 1998; 13(1): 165-8. Epub 1998/03/25. PMid: 9512251.
[30] Sakkas D, Jaquenoud N, Leppens G, et al. Comparison of results after in-vitro fertilized human embryos are cultured in routine medium and in coculture on Vero cells: a randomized study. Fertility and sterility. 1994; 61(3): 521-5. Epub 1994/03/01. PMid: 8137977.

[31] Jayot S, Parneix I, Verdaguer S, et al. Coculture of embryos on homologous endometrial cells in patients with repeated failures of implantation. Fertility and sterility. 1995; 63(1): 109-14. Epub 1995/01/01. PMid: 7805897.

[32] Nieto FS, Watkins WB, Lopata A, et al. The effects of coculture with autologous cryopreserved endometrial cells on human in-vitro fertilization and early embryo morphology: a randomized study. Journal of assisted reproduction and genetics. 1996; 13(5): 386-9. Epub 1996/05/01. PMid: 8739053

[33] Spandorfer SD, Barmat L, Navarro J, et al. Autologous endometrial coculture in patients with a previous history of poor quality embryos. Journal of assisted reproduction and genetics. 2002; 19(7): 309-12. Epub 2002/08/10. PMid: 12168730.

[34] Spandorfer SD, Pascal P, Parks J, et al. Autologous endometrial coculture in patients with IVF failure: outcome of the first 1,030 cases. The Journal of reproductive medicine. 2004; 49(6): 463-7. Epub 2004/07/31. PMid: 15283055.

[35] Spandorfer SD, Barmat LI, Liu HC, et al. Granulocyte macrophagecolony stimulating factor production by autologous endometrial coculture is associated with outcome for in-vitro fertilization patients with a history of multiple implantation failures. Am J Reprod Immunol. 1998; 40(5): 377-81. Epub 1998/12/31. PMid: 9870083.

[36] Simon C, Mercader A, Garcia-Velasco J, et al. Coculture of human embryos with autologous human endometrial epithelial cells in patients with implantation failure. The Journal of clinical endocrinology and metabolism. 1999; 84(8): 2638-46. Epub 1999/08/12. PMid: 10443653. http://dx.doi.org/10.1210/jcem.84.8.5873

[37] Mercader A, Garcia-Velasco JA, Escudero E, et al. Clinical experience and perinatal outcome of blastocyst transfer after coculture of human embryos with human endometrial epithelial cells: a 5-year follow-up study. Fertility and sterility. 2003; 80(5): 1162-8. Epub 2003/11/11. PMid: 14607568.

[38] Dominguez F, Gadea B, Mercader A, et al. Embryologic outcome and secretome profile of implanted blastocysts obtained after coculture in human endometrial epithelial cells versus the sequential system. Fertility and sterility. 2010; 93(3): 774-82 e1. Epub 2008/12/09. PMid: 19062008. http://dx.doi.org/10.1016/j.fertnster t.2008.10.019

[39] Eyheremendy V, Raffo FG, Papayannis M, et al. Beneficial effect of autologous endometrial cell coculture in patients with repeated implantation failure. Fertility and sterility. 2010; 93(3): 769-73. Epub 2009/2/26. PMid: 19249034.

[40] Kattal N, Cohen J, Barmat LI. Role of coculture in human in-vitro fertilization: a meta-analysis. Fertility and sterility. 2008; 90(4): 1069-76. Epub 2008/05/21. PMid: 18490016. http://dx.doi.o $\mathrm{rg} / 10.1016 / \mathrm{j}$. fertnstert.2007.07.1349

[41] Markmann JF, Desai NM, Bassiri H, et al. Prolonged survival of class I deficient mouse islet allografts but not xenografts. Transplantation proceedings. 1994; 26(2): 748. Epub 1994/04/01. PMid: 8171641.

[42] Desai NN, Goldfarb JM. Growth factor/cytokine secretion by a permanent human endometrial cell line with embryotrophic properties. Journal of assisted reproduction and genetics. 1996; 13(7): 546-50. Epub 1996/08/01. PMid: 8844310. http://dx.doi.org/10.10 07/BF02066606

[43] Desai N, Abdelhafez F, Bedaiwy MA, et al. Live births in poor prognosis IVF patients using a novel non-contact human endometrial co-culture system. Reproductive biomedicine online. 2008; 16(6): 869-74. Epub 2008/06/14. PMid: 18549698. 